\title{
THE ANALYSIS OF SOME WELL-KNOWN ROCKS.
}

\author{
By Nicholas KNIGHT, \\ Cornell College.
}

1. The Rock of Which the Houses of Parliament Are Constructed. The specimen was sent tus some months ago by the Right Honorable John Burns, member of the British Cabinet. We read in one of the popular magazines that the rock in the Parliament buildings is quite rapidly weathering and crumbling, which indeed a close inspection of the building readily confirms. We desired to make the chemical analysis to ascertain, if possible, the reason for the crumbling. The rock is a beautiful buff color when first quarried, and on a fresh fracture, but it is blackened by the London smoke, except in some of the more protected angles. The smoke is so thick on the rock that it can be easily rubbed off by a piece of paper or a handerchief, which we tested in many places throughout the building. The analysis was made by Miss Bonnybel Artis, and the figures obtained are as follows:

Per cent.

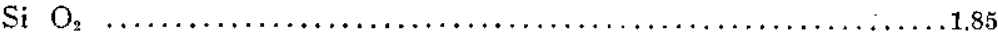

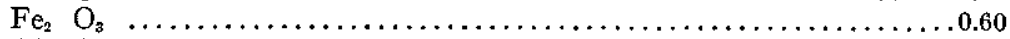

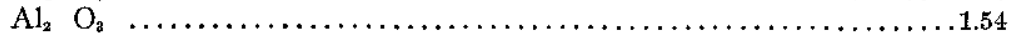

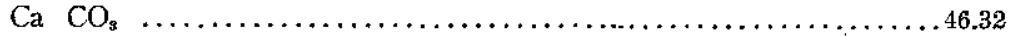

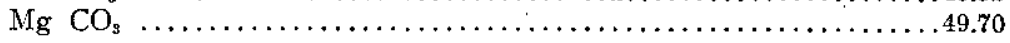

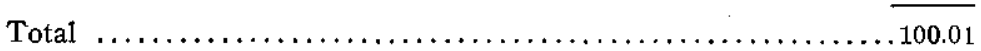

The specific gravity is 2.60 .

J. Allen Howe, curator of the Jermyn Street Museum, London, writes :

"At the request of Sir Archibald Geikie, I have pleasure in sending you the following short note on 'Anston Stone,' used in the Houses of Parliament.

"Auston Stone is, as you say, a dolomite and light buff in color on the fresh fractured surface. It still retains traces of this tint in some of the inner quadrangles of the building, but where more exposed it has become a dark gray. I am quite unable to explain why it should have appeared to you to be red, unless it was seen about sunset.

"The stone comes from quarries at Kiveton Park, east of Sheffield in Yorkshire, where it occurs in the magnesian limestone division of the Permian formation. Other quarries in the same kind of stone are worked at Steetley and Mansfield (red and white). Very little sandstone is used by London builders."

The stone is used in many of the public buildings of London, such as the Bank of England, the Mansion House, Westminster Abbey, St. Paul's Cathedral, and also in many private houses. Neither the chemical composition nor the physical characteristics explain the weathering of the rock. In appearance it seems not unlike, or at least not widely different from, the Roman travertine, which is still standing in buildings erected 2,500 years ago. The Houses of Parliament were constructed in 1846-62. We desire to record our thanks to Honorable John Burns for so kindly taking the trouble to send us a large specimen of the rock.

\section{Red SAnpstone from the Vosges Mountains.}

This is a handsome, durable rock from the Vosges Mountains, of which the Strassburg Cathedral and other public buildings in the city are constructed. The most interesting of all the buildings is the cathedral. The first church was erected in $600 \mathrm{~A}$. D., and the present structure in the eleventh and twelfth centuries. It is a mixture of Romanesque and Gothic. 
The most beautiful portion is the facade, which is also the purest Gothic, a form of architecture that originated in northern France. The numerous statues of prophets, sibyls and apostles and the fine carvings in the stone, like crytallized lace, show how the material is adapted to the most beautifully artistic stone work. The tower is nearly 500 feet in height, and therefore one of the tallest structures in Europe. It is likewise Gothic, and exquisitely wrought, although in many places hit by the shells of the Prussians in the War of '70-'72. The rock is easily transported from the quarries in the mountains on the River Ill, which bisects the city of Strassburg.

The analysis was made by Ellery Botts, and resulted as follows:

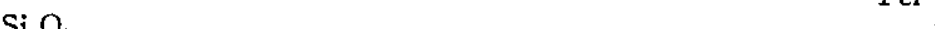

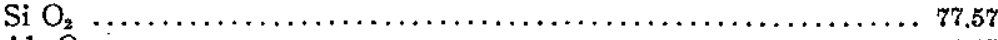

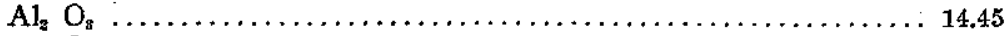

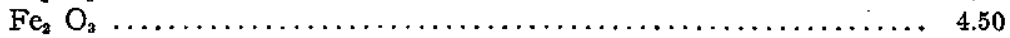

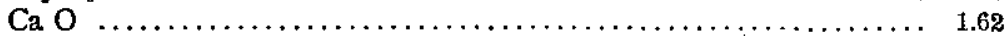

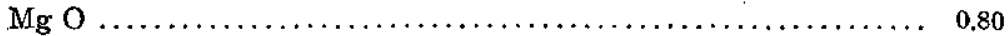

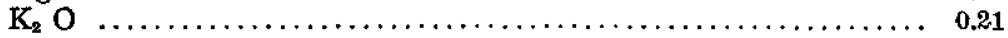

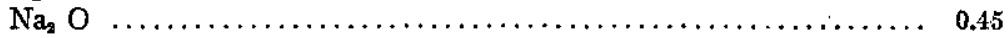

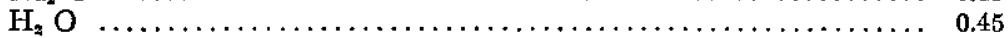

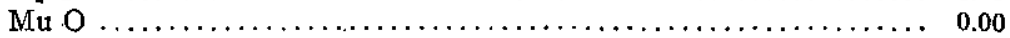

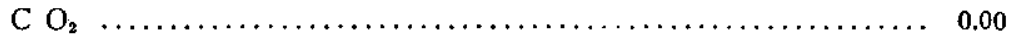

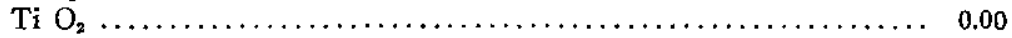

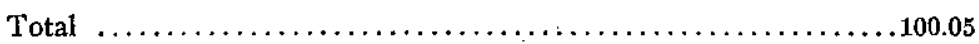

America, doubtless, has as fine and durable building stones as any quarter of the globe, but the high cost of labor has prohibited their use to the fullest extent. As wood has advanced greatly in price in recent years, this may result in a wider use of American building stones.

\section{EARTH RESISTIVITY.}

Oil in sand or earth causes it to have a very high resistance to the flow of an electrical current, that is, speaking technically, to have a very high resistivity. Certain valuable ores in the earth cause it to have a very low resistivity. For any particular specimen of earth the resistivity varies with the moisture content. The damage to pipe systems on account of electrolysis by the return current of street railway systems depends among other things upon the resistivity of the earth around the pipes and near the tracks. There are therefore many reasons why we may wish to know the resistivity of certain very limited portions of the earth.

In a recent publication of the Bureau of Standards, Department of Commerce, a method for measuring earth resistivity which is free from some of the faults of methods which have previously been used is described. The method is particularly adapted to those cases in which it is important that the measurement be made without disturbing the earth, as is necessary where a sample is taken into the laboratory for measurement, and in those cases where we wish to measure resistivity of a fairly large portion of earth, extending to a considerable depth.

To those interested, a copy of the paper, Scientific Paper, No. 258, will be sent on request addressed to the Director, Bureat1 of Standards, Washington, D. C. 